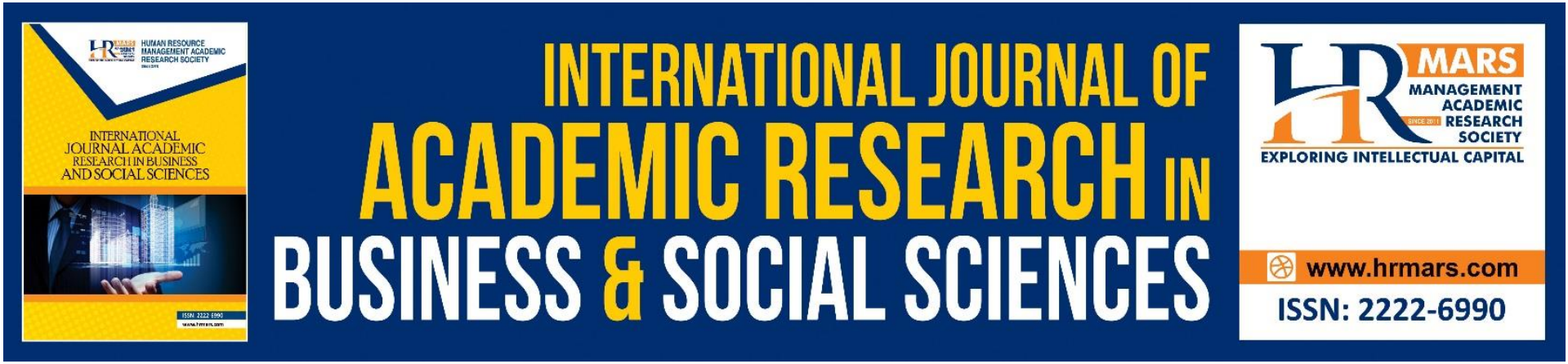

\title{
An Exploratory Study on Challenges of Undergraduates Entrepreneurs: A Case Study in Malaysia
}

Neeta Jayabalan, Sudhashini Nair, Vimala Kadiresan, Dineswary Nadarajan, Mahiswaran Selvanathan

To Link this Article: http://dx.doi.org/10.6007/IJARBSS/v10-i11/9076

DOI:10.6007/IJARBSS/v10-i11/9076

Received: 13 September 2020, Revised: 17 October 2020, Accepted: 19 November 2020

Published Online: 26 November 2020

In-Text Citation: (Jayabalan et al., 2020)

To Cite this Article: Jayabalan, N., Nair, S., Kadiresan, V., Nadarajan, D., \& Selvanathan, M. (2020). An Exploratory Study on Challenges of Undergraduates Entrepreneurs: A Case Study in Malaysia. International Journal of Academic Research in Business and Social Sciences, 10(11), 1507-1516.

Copyright: (c) 2020 The Author(s)

Published by Human Resource Management Academic Research Society (www.hrmars.com)

This article is published under the Creative Commons Attribution (CC BY 4.0) license. Anyone may reproduce, distribute, translate and create derivative works of this article (for both commercial and non-commercial purposes), subject to full attribution to the original publication and authors. The full terms of this license may be seen at: http://creativecommons.org/licences/by/4.0/legalcode

Vol. 10, No. 11, 2020, Pg. 1507 - 1516

http://hrmars.com/index.php/pages/detail/IJARBSS

JOURNAL HOMEPAGE

Full Terms \& Conditions of access and use can be found at http://hrmars.com/index.php/pages/detail/publication-ethics 


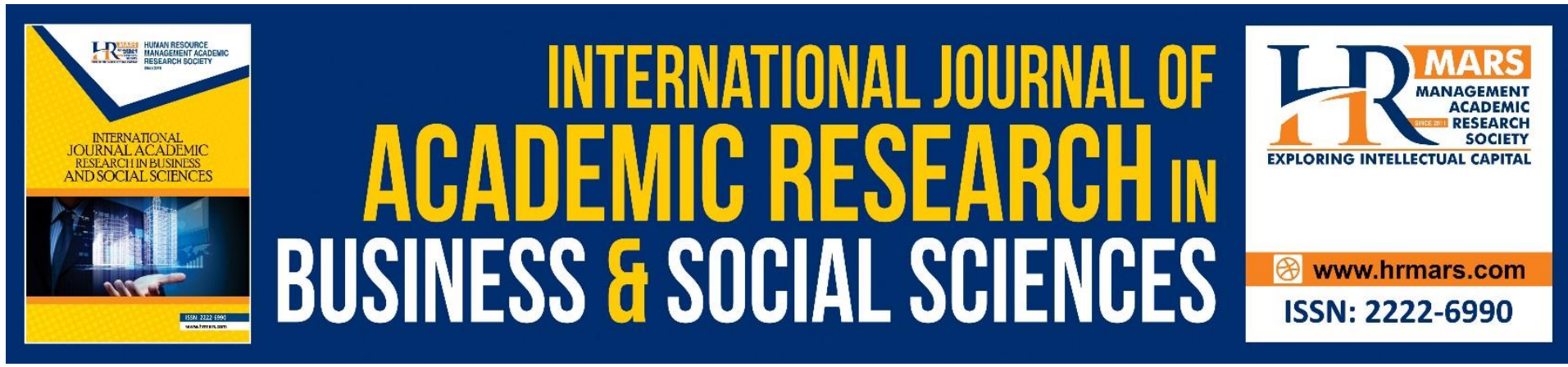

\title{
An Exploratory Study on Challenges of Undergraduates Entrepreneurs: A Case Study in Malaysia
}

\author{
Neeta Jayabalan ${ }^{1}$, Sudhashini Nair ${ }^{1}$, Vimala Kadiresan², \\ Dineswary Nadarajan ${ }^{1}$, Mahiswaran Selvanathan ${ }^{3}$ \\ ${ }^{1}$ SEGi University, Kota Damansara, Petaling Jaya, Malaysia, ${ }^{2}$ HELP University, Kota \\ Damansara, Petaling Jaya, Malaysia, ${ }^{3}$ University Sains Malaysia, Bayan Lepas, Penang.
}

\begin{abstract}
Entrepreneurship is complex because the dynamic advantage attained by entrepreneurs generally progresses along with a nation's economic development. Undergraduate entrepreneurs are the key talent providers for the successful fiscal progress of a nation in the commercial context. The challenges of venturing into entrepreneurship are found in the startup phase and in the transition of youths who may have missed out on numerous business prospects occurring at the local, regional, and national levels of a country. Therefore, the aim of this study is to investigative the challenges faced by undergraduates and ascertain if business prospects are of great importance in nurturing successful undergraduate entrepreneurs in Malaysia. A qualitative method was used in the study (Creswell, 2014). Ten undergraduates participated in the study, who were chosen purposively as they were actively involved in business sectors. The findings indicate there were five crucial challenges faced by undergraduates in venturing into business: social rejection, facing criticism, financial constraints, dealing with stress and self-doubt, and facing age stereotypes. These were effective factors because the entrepreneurs lacked knowledge and exposure due to their youth and limited access to millennium business approaches. Further studies can be undertaken to determine entrepreneurial initiators' capabilities and gauge their capacities in relation to various aspects of entrepreneurship to establish the capabilities required of millennials. Such research may corroborate the findings of this study and correlate with the challenges faced in entrepreneurial business contexts.
\end{abstract}

Keywords: Knowledge, Challenges, Undergraduate's Entrepreneurs, Malaysia

\section{Introduction}

The concept of entrepreneur holds a close relationship with its current definition which has moved to include broader functions related to delivering elevated yield by way of improved output for economic progress. Entrepreneurship has been regarded as an important advantage accrued by business people in the general growth of national economies (Brinda and Dileep, 2011). Besides that, the term entrepreneurship currently points to the whole process of discovery, evaluation, and application of entrepreneurial prospects (Shane 
and Venkataraman, 2000), encompassing new commercial enterprise creation and entrepreneurial endeavours in generating commercial prospects. Entrepreneurship is currently in vogue and commonly discussed. Entrepreneurship is the frequent subject of conversation in social circles, especially among younger people intending to launch start-up companies (Ooi, Selvarajah and Meyer, 2011). Colloquiums, meetings, discussions, and informal get-togethers are being held frequently all over the world which focuses on the importance of entrepreneurship to nations and individuals and for the acquisition of business knowledge (Bechard and Toulouse, 1998; Matlay and Westhead, 2005; Volery and Mueller, 2006). Entrepreneurship, through the formation of new ventures or start-ups that replaces traditional companies, has been recognised as one of the prime movers of fiscal expansion, with business skills playing a major part in young entrepreneurship (Wennekers and Thurik, 1999).

There are numerous influences affecting young entrepreneurs' reasons and objectives for going into entrepreneurship. However, because of their lack of entrepreneurial knowledge and today's competitive job market, work openings generally go to the best-suited candidates. Lakshmanan, 2017; Ooi, Selvarajah and Meyer, 2011). Furthermore, Ridzwan, Muhammad and Rahman (2017) established that only about $20 \%$ of young entrepreneurs achieve success in business ventures yearly, which indicates that the success rate for young entrepreneurs in Malaysia is rather low. Since undergraduates desire to excel as entrepreneurs and be recognised as successful businessmen, these young entrepreneurs need to have the right business skills to enhance economic development in the country. Consequently, these undergraduate entrepreneurs are seeking to equip themselves with adequate business knowledge and entrepreneurial skills in order to successfully run business ventures and at the same time, create job openings (Brown, 1999; Henry, 2003). Hence, to advance entrepreneurship and business in the country, the Malaysian government has undertaken numerous programs to support entrepreneurship as a potentially gainful profession for university students to seriously consider (Mohamad Radzi, Mohd Nor, and Mohezar Ali, 2017). Indeed, the Malaysian government has made available various forms of assistance to facilitate the acquisition of educational knowledge in entrepreneurship, particularly for undergraduates (Mohamad Radzi, Mohd Nor, and Mohezar Ali, 2017). Therefore, the aim of the present study is to examine the effectiveness of undergraduates having adequate knowledge for achieving success as entrepreneurs in Malaysia.

\section{Literature Review}

\section{A. Undergraduates Entrepreneurs}

The United Nations defines youth as individuals between the ages of 15 to 24 years old, though in Malaysia, six states consider people between the ages of 15 to 20 years as youth. This has some similarity to the definition provided by the Malaysian Youth Council in 2007, where young people aged 15 years and above but not older than 40 are considered as a youth. It is this age grouping that is considered to be forward thinking, mature in their thoughts, and highly competitive (Kamal et al., 2013). Additionally, a few entrepreneurial investigators have ascertained that smart entrepreneurs have good dispositions, such as being personable and sociable, understand the intricacies of commerce, and possess a strong determination to further develop their businesses (Chan, Selvadurai and Bahiyah, 2009). 
This attitude is not only found in older entrepreneurs but also among younger entrepreneurs, meaning that these are the primary attributes that determine if a youth has what it takes to be an entrepreneur (Chan, Selvadurai and Bahiyah, 2009). It is further explained that the basis for young entrepreneurs being successful is the accumulation of business accomplishments combined with the necessary skills and personal touch that underline the advancement of their entrepreneurial journey (Inc. Crum, Sherony and Rayome, 2015). Based on research by Kauffman (2015), a person's entrepreneurial experience is an important factor in determining their entrepreneurial objective and enterprise. Entrepreneurial experience denotes a person's business-related background and commercecentred education as well as their ambition to become an entrepreneur. This is further supported and validated by Nyambura (2016), who notes that education and learning alone does not necessarily constitute enhanced ability and performance but may provide an opportunity for future ventures. For entrepreneurs of all categories, the need for knowledge is augmented because of the highly competitive environment that pervades the commercial world. As a result, much focus is given to knowledge sharing by administrators and scholars, who maintain that relevant information will enable a company to achieve its commercial targets and assist in fostering a tradition of systematic learning (Leung, 2015). As stated above, entrepreneurial experience can be categorised into three areas. An entrepreneur's nurturing is centred on the person's family surroundings. In the view of (Seng, Mitchell and Marin, 2015), individuals who are constantly subjected to commercial ideas and activities are more apt to become successful in business. The reason is that affluent parents are more likely to educate their kids to become outstanding and skilled personalities. This special support and assistance will enable the children to have a clear and initial benefit that will help them learn more quickly. Secondly, there is educational background.

\section{B. Entrepreneurial Knowledge}

Many research studies have established the constructive connection between adequate education and entrepreneurial success (Jiao and Cui, 2014). This opinion is shared by Qudah and Safizal (2014), who state that since education enlarges and improves the entrepreneur's knowledge of commercial activities, the entrepreneur will become more skilled in making vital business decisions. Thirdly, entrepreneurial experiences and knowhow are comprised of prior appropriate job skills, specialized skills relevant to the industry, and managerial skills (Riga, 2016). Based on a study conducted by Sharma and Madan (2014), the accrual of entrepreneurial knowledge develops the worth of entrepreneurs' business enterprises as the accumulated skills enable them to successfully overcome problems from a knowledge perspective.

A person's business acumen can be ascribed to various facets of entrepreneurial ability. The more knowledgeable an entrepreneur is on specific skills, the more capable he or she will be (Eser and Ozdemirce, 2016; Rahim, Kadir and Abidin, 2015). Entrepreneurial abilities can be classified into a few areas. Firstly, interpersonal skills permit an entrepreneur to have good communication with important people, like customers, friends, and associates. Interpersonal skills come from the entrepreneur's skills in reading body language, understanding personality and intentions, speaking ability, and wide-ranging general knowledge (Ali, Ishaya and Hassan, 2015). These skills enable the entrepreneur to have good management control of employee-related matters of his/her business concerns and draw major commercial contracts. Secondly, resilience is considered to be a strong incentive that compels an 
entrepreneur to work harder and better than his/her colleagues (Potter, 2014; Yee, Chong and Kendall, 2015). Being highly focused is normally associated with having a competitive spirit, which enables the entrepreneur to maintain relevancy in complex business settings. Having vast knowledge about various issues enables an entrepreneur to solve issues in a satisfactory and fair manner. The entrepreneurs' depth of knowledge enables them to devise the best solutions (Ridzwan, Muhammad and Rahman, 2017; Sitoula, 2015). The same methodology is applied in making correct evaluations, which entails having in-depth knowledge of current issues to enable making correct decisions the norm. Fourthly, business fundamentals are required for every entrepreneur entering the business world to have the basic expertise to realise his or her plans. Having in-depth information about the economy, the fundamentals of company operations, managerial expertise, and devising ways to tackle the competition are some of the business tenets that an entrepreneur should have in their repertoire (Basu and Virick, 2016).

\section{Entrepreneurial Challenges}

Generally, having precise information on various business procedures and applying it effectively will lead to positive outcomes in commercial ventures by entrepreneurs in Malaysia. On the basis of the information provided above, it has been established that there is a connection between accumulation of relevant knowledge in order to face the challenges and success in business by young entrepreneurs. There has been a study done on youth entrepreneurship by Nguyen and Phan (2014) on the entrepreneurship of young people aged between 25 to 40 years old in Malaysia. The result from the study shows that influences of socio-cultural background such as religion and ethnic factors impact the progress of entrepreneurship. Correspondingly, psychological aspects like risk-taking, efficiency, and being desirous of knowledge acquisition also have crucial impacts on the success of new commercial ventures among youth in Malaysia (Chan, Selvadurai and Bahiyah, 2009). From the above studies, it was shown that young people are currently keen to venture into the retail and trading segments but are hesitant because of a lack of sufficient business knowledge and experience.

In the opinion of Sitoula (2015), youths from all over the world are faced with a lack of job opportunities in the $21^{\text {st }}$ century. According to Kauffman (2015), youth entrepreneurship is considered to be the most viable vehicle for youth job creation and producing sustainable development in countries and among social groups, especially in nations where youths form a major part of the population. In addition, the youth establish that entrepreneurship will receive greater recognition and gain more traction among the young, creating a pathway to financial independence, maintaining reasonable living standards, and creating jobs (Lakshmanan, 2017). On the other hand, disputes that youth entrepreneurship is a proven method of better equipping youth for incorporation into the current globalised labour markets. Nevertheless, Eser and Ozdemirci (2016) point out that there are historical antecedents showing that having sufficient knowledge is a crucial factor in the success of entrepreneurs in Malaysia. It is also pertinent that all of the above studies were conducted based on questionnaires and the subjects were not involved in real contexts such as participant meetings. In conclusion, it is of vital importance for a study to be undertaken to investigate and establish how the accrual of challenges relates to the success of young entrepreneurs among undergraduates in Malaysia. 


\section{Methodology}

This study utilized a qualitative method (Creswell, 2014). Ten undergraduate students participated in this study. These undergraduates were pursuing their bachelor's programs in various fields such as Industrial Engineering, Chemistry, Mass Communication, Management, Marketing, Business and Teaching English as Second Language (TESL). These undergraduates were 20 to 23 years old and were involved in t-shirt and banner printing; selling food during breakfast, lunch, and dinner; Photostatting and running tuition centres in the university and its vicinity. The respondents were purposively sampled (Creswell, 2014) and the data was collected in real contexts during their business hours. They were also chosen based on convenience (Creswell, 2014). Although the sample size was small, (Li, 2002; Wodak, 2013) noted that due to some cases' stringent requirements to obtain emergent authentic data, even one excerpt could be considered a significant contribution to a study.

Impromptu interviews were conducted with the 10 selected undergraduates. As this was impromptu interviews, the conversation was recorded and transcribed without using any transcription notation symbols. This was done because the participants requested that the transcribed data not be included in any publication of the research, making the use of notation symbols superfluous.

Results And Discussion

Based on the impromptu interview, it was found that most of the undergraduates were overwhelmed with challenges in sustaining the growth of their businesses. There were five crucial challenges faced by undergraduate entrepreneurs: social rejection, criticism, financial constraints, stress and self-doubt, and age stereotypes. Regarding the first challenge faced by the young entrepreneurs, social rejection, it was found that an undergraduate's immediate household members and colleagues may initially feel somewhat perplexed as to why one of them chose to take up business as a career instead of taking up a regular job. They may feel reluctant to support his or her ambition. The undergraduate might feel disheartened and uncertain about succeeding in his or her chosen career in view of the lukewarm support from family members, but these negative thoughts and feelings will slowly dissipate as the undergraduate gets help and advice from colleagues and friends who have become successful entrepreneurs. Being successful in the chosen business will further boost the confidence of the undergraduate that he or she is on the right course. Secondly, when facing criticism, young undergraduates involving themselves in entrepreneurship are bound to be disparaged by some people as some feel or assume that fresh graduates are supposed to work and earn money before moving on to other things like becoming business people. Some will constantly evaluate all their business decisions and say they could have done better. Others will constantly seek ways and means to find shortcomings in their decisions and try to dissuade them from continuing with their career plans. While some of these criticisms may be made out of concern that the undergraduates have made the wrong decision, others may have ulterior motives such as not wanting these new entrepreneurs to succeed. Thirdly, in regard to financial constraints, the road to achieving success for many young undergraduate entrepreneurs is lined with many obstacles, especially financial ones. They need funding to start a business but may be bogged down with paying off loans like student education and covering other financial costs. While their ambition may be to become successful entrepreneurs, realizing the dream is reserved for the most determined and skilled ones.

Getting the necessary funding to set up and sustain a business will be the initial difficulty young entrepreneurs will encounter, but once the cash flow situation stabilizes and they are able to meet the monthly payments, their enterprise can be considered to be on the path to 
success. A steady cash flow is vital for small businesses to succeed; otherwise entrepreneurs may face problems paying bills. Problems could arise if entrepreneurs are slack in their business dealings, such as sending out invoices late, failure to send reminders, or poor record keeping. The fourth challenge is dealing with stress and self-doubt. One of the issues that most undergraduate entrepreneurs will face along the way to achieving success is entrepreneurial depression. While business can be rewarding to entrepreneurs, it can also bring endless pain, suffering, and disappointment, especially during the initial stages when the business is being developed. Anxiety, stress, and self-doubt can creep in during this developmental stage when the entrepreneurs may be faced with insufficient cash flow, unpaid bills, or creditors threatening legal action. Some entrepreneurs will succumb to these pressures, while others may persevere and eventually succeed. Therefore, undergraduates must gain sufficient knowledge in business, for instance by working in a business, to avoid as well as to overcome problems when they set up a business. The final challenge is facing age stereotypes. The results indicate that perception of undergraduate entrepreneurs can be affected by generational beliefs and ideas. Older adults who are more used to working for a salary might consider the junior entrepreneur's decision as hasty and irresponsible and unlikely to work. Fellow entrepreneurs may also have negative feelings regarding the undergraduate's ability to sustain the business, which could be rather discouraging. The determined entrepreneur should be able to overcome the various obstacles by working hard and getting help, support, and encouragement from likeminded people who believe that young people should be given all the help needed to succeed in business. Cultivating the support of family members and close friends is important, even though some of them may have been critical of the undergraduate's decision to enter into business. It is important that young entrepreneurs engage with friends and family members from time to time to garner their support and assistance and also convince them that they have made the right decision. Nevertheless, there will always be people who will be unsupportive of young undergraduate entrepreneurs and may constantly criticize and find fault with their ideas and ambitions. The constant negative comments should not put off the entrepreneurs from their vision, but rather this should energise them to work hard and succeed in their business. However, the entrepreneurs should also be acutely aware of the reality of business, which is that a business can fail, or it can succeed. As such, undergraduates should be well prepared before they plunge into the business world. Entrepreneurs should have some business knowledge, practical training, sound financial planning, and even mentors to advise and guide them when they set up their businesses so that their businesses move forward on sound footing and there are fewer chances that mistakes will occur that can jeopardize their business success. Apart from all these challenges, it was found that they also lacked getting sufficient knowledge, and knowledge plays an important role in entrepreneurial success (Sani, 2018).

\section{Conclusion}

It is very clear and apparent that having adequate knowledge is the key to solving the many challenges faced by young entrepreneurs. The entrepreneurial endeavors contribute greatly to economic progress and creating new job opportunities. However, there are opinions uttered that a few entrepreneur's actions focusing on social needs could lead to the commercialization of non-profit bodies, which may not reflect society's needs. Nevertheless, entrepreneurial pursuit in general can also be beneficial as society and undergraduates could learn and garner valuable information from the community. Opportunities to undertake entrepreneurial activities could be increased with more focus and the necessary resources 
being made available. Moreover, this could also assist in formulating new economic, social, institutional, and cultural settings. It then follows that from the combining of skills and the accessibility of business assets, success can be achieved if the assets are employed effectively, deliberately, and imaginatively. While the issue of some young entrepreneurs flourishing while others are not is quite complex and has been a subject of debate in developing countries, empirical studies have not found robust data sustaining this proposition. There are still some issues that are not clearly understood as to why some entrepreneurs are more successful than others. Investigations on youth entrepreneur accomplishments do not show much evidence to support indications from the previous studies as mentioned earlier that entrepreneurs' success in business was connected to basic factors of entrepreneurship challenges. Young undergraduate entrepreneurs in Malaysia are faced with a lot of pressure as the country gradually merges into the global economic order. Therefore, a systematic study of the way young entrepreneurs employs their assets to develop their business models is vital as this will result in the development of new instruments such as (1) ways for businesses to upgrade their innovation and development methods and (2) tools for the nation to use in developing fresh ideas to encourage economic expansion. Further studies can be undertaken to determine entrepreneurial initiators' capabilities and gauge their capacities in relation to various aspects of entrepreneurship to establish the capabilities required of millennials. Such research may corroborate the findings of this study and correlate with the challenges faced in entrepreneurial business contexts.

\section{References}

Creswell, J. (2014). Research Design: Qualitative, Quantitative, and Mixed Methods Approaches ( $4^{\text {th }}$ ed.) SAGE Publications.

Brinda, K.P.R., \& Dileep, K. M. (2011). Motivational factors, entrepreneurship and education: Study with reference to women in SMEs. Far East journal of psychology and business, 2 (1), 12-19.

Shane, S., \& Venkataraman, S. (2000). The promise of entrepreneurship as a field of research. The Academy of Management Review., 25(1), 217- 226.

Ooi, Y. K., Selvarajah, C., \& Meyer, D. (2011). Inclination towards entrepreneurship among university students: An empirical study of Malaysian university students. International Journal of Business and Social Science, 2 (4),206-220.

Bechard, J. P., \& Toulouse, J. M. (1998). Validation of a didactic model for the analysis of training objectives in entrepreneurship. Journal of Business Venturing, 13(2), 317-332.

Matlay, H., \& Westhead, P. (2005). Virtual teams and the rise of e-entrepreneurship in Europe. International Small Business Journal, 12(3), 353-365.

Volery, T., \& Mueller, S. (2006). A conceptual framework for testing the effectiveness of entrepreneurship education programmes towards entrepreneurial intention. 51st ICSB World Conference Melbourne, Australia.

Wennekers, A. R. M., \& Thurik, A. R. (1999). Linking entrepreneurship and economic growth. Small Business Economics, 13 (2), 27-55.

Lakshmanan, L. (2017). Predictions of Financial Distress in Malaysia. University Tunku Abdul Rahman, 1-109.

Ridzwan, R., Muhammad, N. M., \& Rahman, A. A. (2017). Issues and Challenges among Young Entrepreneurs in Malaysia. IOSR Journal of Business and Management, 19(3), 80-84.

Brown, C. (1999). Teaching new dogs new tricks: The rise of entrepreneurship education in graduate schools of business. DIGEST, 99(2): 1-4. 
Henry, B. (2003). Entrepreneurship education in Kenya: A reality or plodding on? The First International Entrepreneurship Conference, 3(25), 23-32.

Khadijah, M. R., Mohammad, N. M. N., \& Suhana, M. Ali. (2017). The impact of internal factors on small business success: A case of small enterprises under the FELDA scheme. Asian Academy of Management Journal, 22(1), 27-55.

https://doi.org/10.21315/aamj2017.22.1.2.

Kamal, C. P., Azimi, H., Bahaman, A. S., Ismi, A. I., \& D’Silva, J. L. (2013). Rural Malay involvement in Malaysian herbal entrepreneurship, Asian Social Science, 10 (2), 202208.

Chan, K. L., Selvadurai, S., \& Bahiyah, A. H. (2009). Malay youth entrepreneurship in Malaysia: An empirical update, Malaysian Journal of Society and Space, 2(2), 55-67.

Crum, M. D., Sherony, B., \& Rayome, D. (2015). Human Capital and Self-employment: The Moderating Effect of Economic Freedom. International Journal of Entrepreneurship, 19, 1-199.

Kauffman. (2015). The Future of Entrepreneurship: Millennials and Boomers Chart the Course for 2020. State of Entrepreneurship Address, 1-20.

Nyambura, I. M. (2016). Factors influencing success of youth entrepreneurs hip in Kenya: A case study of Nailab youth entrepreneur's incubation project. United States International University - Africa, 1-74.

Leung, L. (2015), Validity, reliability, and generalizability in qualitative research. Journal of Family Medicine and Primary Care, 4(3), 324-327.

Seng, B. R., Mitchell, R. K., \& Marin, A. (2015). Job Security and Entrepreneurship: Enemies or Allies? Journal of Applied Management and Entrepreneurship, 20,(2) 24-49.

Jiao, H., \& Cui, Y. (2014). Building entrepreneurs' innovativeness through knowledge management: the mediating effect of entrepreneurial alertness. Technology Analysis \& Strategic Management, 26(5), 501-516.

Qudah, M. K., \& Safizal, M. A. (2014). Critical Success Factors of Organizational Performance: A Study of Small and Medium Enterprises in Jordan. Journal of Humanities and Social Science, 19(6), 53-57.

Riga, A. (2016). Impact of motivational factors of nascent entrepreneurs on business surviving success. University of Latvia Faculty of Economics and Management, 4(2), 1-145.

Sharma, L., \& Madan, P. (2014). Effect of individual factors on youth entrepreneurship-a study of Uttarakhand state, India. Journal of Global Entrepreneurship Research, 2(3), 1-17.

Eser, G., \& Ozdemirci, A. (2016). Personality Characteristics and Business Philosophy: An Entrepreneurship Experiment. European Journal of Business and Social Sciences, 4(11), 70-87.

Rahim, H. L., Kadir, M. A., \& Abidin, Z. Z. (2015). Entrepreneurship Education in Malaysia: A Critical Review. Journal of Technology Management and Business, 2(2), 1-11.

Zaman, A., \& Ishaku, I., \& Haslinda, H. (2015). The Critical Success Factors of e-CRM Implementation to Small and Medium Enterprises. International Conference on Ecommerce, 5(11), 1-12

Potter, J. (2014). Supporting Youth in Entrepreneurship. European Commission Directorate General for Employment, Social Affairs and Inclusion, 1-27.

Yee, A. S., Chong, A. L., \& Kendall, G. (2015). Managing University-Industry Collaborations in Malaysia by Examining its Critical Success Factors: A Dyadic Approach. World Review of Business Research, 5(3), 213-230. 
Sitoula, T. A. (2015). Challenges and Prospects of youth entrepreneurship in Kathmandu. University of Nordland, 1-123.

Basu, A., \& Virick, M. (2016). Silicon Valley's Indian diaspora: networking and entrepreneurial success. South Asian Journal of Global Business Research, 4(2), 190-208.

Nguyen, M., \& Phan, A. (2014). Entrepreneurial traits and motivations of the youth-an empirical study in Ho Chi Minh City-Vietnam, International Journal of Business and Social Science, 5(1), 53-62

Li, W. (2002). What do You Want Me to Say?' On the Conversation Analysis Approach to Bilingual Interaction. Language in Society-Lang Soc, 31, 02-28.

Wodak, R. (2013). Critical Discourse Analysis-Challenges and Perspectives. In R. Wodak (Ed.), Critical Discourse Analysis. ISBN 9781446210581. 